\title{
Analysis of Learning Higher Order Thinking Skill (HOTS) Toward English Subject
}

\author{
Putu Sri Warmadewi' ${ }^{1}$, Dewa Ayu Eka Agustini' ${ }^{2}$, \& Nyoman Karina Wedhanti ${ }^{3}$ \\ ${ }^{123}$ English Language Education, Universitas Pendidikan Ganesha, Indonesia
}

\begin{tabular}{|c|c|}
\hline & ABSTRACT \\
\hline $\begin{array}{l}\text { Keywords: } \\
\text { Assessment, } \\
\text { Higher Order Thinking Skill } \\
\text { (HOTS), } \\
\text { Lesson Plan }\end{array}$ & $\begin{array}{l}\text { Abstract: In line with the } 21^{\text {st }} \text { century learning of education, } 2013 \text { Curriculum } \\
\text { ( } k \text {-13) highlights the development of critical thinking, problem analyzing, } \\
\text { problem solving, decision making, and creating something new. It requires } \\
\text { teachers to use the new paradigm in designing the lesson plan as well as the } \\
\text { assessment, which indicate Higher Order Thinking Skill (HOTS). However, the } \\
\text { implementation does not work properly as planned. Therefore this research } \\
\text { aimed to analyze the implementation of Higher Order Thinking Skill (HOTS) in } \\
\text { terms of designing the content of lesson plans and assessments at SMA Negeri } \\
2 \text { Banjar. This was a qualitative research employing a document study design. } \\
\text { The subject of this study was the English teacher in SMA Negeri } 2 \text { Banjar. The } \\
\text { data were collected qualitatively through observation, documentation and } \\
\text { interview. The results showed that Higher Order Thinking Skill (HOTS) was not } \\
\text { expressed in the whole of the lesson plan and the assessment, it was covered } \\
\text { in several parts of the lesson plan as well as the assessment. The results has } \\
\text { the implication for the English teacher to develop the implementation of } \\
\text { Higher Order Thinking (HOT) in the content of the lesson plan and assessment } \\
\text { holistically. }\end{array}$ \\
\hline
\end{tabular}

Correspondance address:

E-mail: putu.sri.warmadewi@gmail.com (Putu Sri Wardani)

\section{Introduction}

In the $21^{\text {st }}$ century of education, the teaching learning process should focus more on critical thinking, problem analyzing, problem solving, decision making, and creating something new. It requires teachers to use the new paradigm in the teaching learning process that is students-centered. However, in the reality it is not in line with the theory. It can be seen from the implementation of learning itself which is still dominated by teacher-centered approach that is characterized by: 1 . Teachers focus to transfer their own knowledge to the students, 2 . the students tend to be passive in the teaching learning process, 3. The learning process is started by the teachers explaining the material then giving the students some exercises, and 4. Learning process still emphasizes learning to know.

Thinking skill is the most basic skill that can be developed in the classroom and it is the key to achieve the goal for all the students. Thinking is a kind of mental activity that is experienced by someone when he or she faces problem, that should be solved (Sulaiman, Muniyan, Madhvan, Hasan , \& Rahim , 2017). Thinking skill is divided into two types, those are High Order Thinking (HOT) and Low Order Thinking (LOT). According to Sulaiman, Muniyan, Madhvan, Hasan , \& Rahim (2017) higher order thinking skill is defined as the use of mind broadly to create or find something new. Higher order thinking skill requires a person to apply the new information and manipulate it to reach possible answers in a new situation. High order thinking skill is thinking at a higher level rather than just memorizing the fact and telling someone the information exactly as he or she is told. 
Talking about thinking stage, Bloom's taxonomy is considered as a basis for higher-order thinking. According to Saido, Siraj, Nordin, \& Al_Amedy (2015) the idea of high order thinking (HOT) is obtained from the Bloom's taxonomy of cognitiv domain. Bloom's taxonomy is categorized into six levels of thinking; knowledge, comprehension, application, analysis, synthesis and evaluation. However, Anderson and Krathwohl revised the Bloom's taxonomy from one dimension into two dimensions, those are cognitive process and types of knowledge. They classified the cognitive process into six categories; remember, understand, apply, analyze, evaluate, and create.

The most important thing in higher order thinking skill is that the ability to make a reasonable decision in the complex situation. It emphasizes "learning how" rather than "learning what". Therefore, the efforts to help individuals to achieve their targets require self awareness that is a part of efforts of the educators to explore higher order thinking skill (Sulaiman, Muniyan, Madhvan, Hasan , \& Rahim , 2017).

Unfortunately, looking at reality now, many educational institutions only emphasize memorizing skill. Higher order thinking skill is very important to be applied in the aspects of knowledge. It is important to be instilled in students, considering that the rapid development of technology requires every individual to mobilize his or her mind and all the potential in order to be able to survive and compete. Educational institutions, which only emphasize memorizing make students unccustomed to thinking critically in accepting material given. As the result, the habit of students who only memorize without developing arguments will continue to college and even in the real world of work.

HOTS-based learning has actually been introduced in line with the implementation of the 2013 Curriculum, but in reality there are still many educators who do not understand and have not implemented it. This is because during the training, the instructors transferred theories solely without giving examples or practices of implementation of HOTS learning.

Related to the explanation above, the researcher decided to choose SMA Negeri 2 Banjar as a place of research because it has already implemented 2013 Curriculum, which means that higher order thinking skill should be imlemented in this school. Beside that, the researcher analyzed whether the 2013 Curriculum has been implemented well by the teachers' who taught English in the first grade at SMA Negeri 2 Banjar. SMA Negeri 2 Banjar is one of the schools which is located in Banjar district, Buleleng regency. This school is located in the rural area in Singaraja. Despite its location, it does not mean that the implementation of curriculum 2013 is considered bad.

In today's education, learning must be directed at improving thinking skill in order to be able to compete in global competition. This can be achieved if education does not solely givan emphasis on the ability to memorize scientific concepts, but also improves students' thinking skill, especially high order thinking skill. It means that the teacher needs to teach students to develop their higher order thinking paradigm. In establishing higher order thinking skill, teachers have an important role to develop the learning components. The role of school in developing higher order thinking skill can be done through the of planning to the evaluation stage such as lesson plan, learning activities, and assessment.

This is done in order to find out the imlementation of learning that is applied by the teacher in a particular school and the students' perceptions of the implementation of learning set by the teacher. By analyzing these three aspects, how the application of learning carried out by the teacher can be seen. Therefore, by doing research on high order thinking skill, it is expected that it can provide new knowledge to the education field, especially for educators, so that they are motivated to improve strategies, models, and learning methods that do not instill memorizing abilities. It must be changed and directed to apply learning that leads to cognitive processes and encourages in improving the ability to think of each student.

Based on the rationale, the research entitled "Analysis of Learning High Order Thinking Skill (HOTS) in English Subject in SMA Negeri 2 Banjar in the Academic Year of 2018/2019" was conducted. 


\section{Methods}

This research employed qualitative approach using document study. Qualitative research is a description of phenomenon that is desired. This method is useful for researchers who want to know about who, what, and where of events (Sandelowski, 2000). While document study is a form of qualitative research in which documents are interpreted by the researcher to give voice and meaning around an assessment topic (Creswell, 2009). This is a document study which attempted to uncover a fact or phenomenon. This study used a formative analysis model where the analysis is carried out on the design of the lesson plan and assessment.

This research was conducted at SMA Negeri 2 Banjar, which is located in Banjar Village, Banjar Sub district, Buleleng Regency. It was conducted at SMA Negeri 2 Banjar because it is one of Senior High Schools in Buleleng Regency which has implemented Curriculum 2013.

The subject of this research is an English teacher in class X SMA Negeri 2 Banjar. Based on the preliminary observation, the subject was selected because the subject is a certified teacher who had an experience in teaching almost 8-9 years at SMA N 2 Banjar and also has attended the workshops about the 2013 Curriculum. The objects of this research were the lesson plans based on the 2013 Curriculum, the implementation of curriculum 2013 in class assessments that contain indicators of high-level thinking skills.

There are ten lesson plans used in this research. Two of them are from the first semester and the rest are from the second semester. This decision was made because the English teacher did not entirely teach in one semester. Therefore, the researcher only could use ten lesson plans from both first and second semester of this study.

To find out whether the design of the lesson plans made by the English teacher have already contained indicators of high-level thinking skills, the researcher conducted analysis on, indicators, learning processes, and student worksheets in the lesson plan. To find out whether the implementation of class assessment activities has led to high-level thinking skills, the researcher conducted an analysis of assessment questions in the lesson plans made by the English teacher. Those assessment questions are stated to be good if the results of the analysis show that the verbs used in the test questions are the verbs of each indicator of high-level thinking skills in the form of analyzing, evaluating, and creating activities.

\section{Results and Discussion}

The development of the 2013 Curriculum aimed to encourage students to be better and able to make observations, ask questions, reason, and communicate. In implementing the 2013 Curriculum, the teachers are encouraged to implement HOTS (Higher Order Thinking Skill) learning and to assess the learning outcome in HOTS aspects of knowledge. Higher Order Thinking Skill (HOTS) defined as an ability to think widely in order to find a new challenge. In higher order thinking includes critical, logical, reflective, creative in thinking and creative problem solving (Mainali, 2012).

The findings were derived from the analysis of ten lesson plans. Indicators were made in the form of operational verbs which should be performed by the students. The indicator of the lesson plans used varied operational verbs, such as showing, identifying, making, creating, retelling, etc. Based on those ten lesson plans there were varied number of indicators for each basic competency. There were about two to three indicators developed for knowledge aspect. For instance; (1) Identifying social function of recount text about historic event, (2) Identifying test structure of recount text about historic event, (3) Identifying language features of recount text about historic event. While for the skill aspect there were about one to two indicators developed. For example; (1) describing orally a tourism object and famous historical building, (2) writing orally essay descriptive text about tourism object and famous historical building. From the result of interview it was found 
that the English teacher, has already to be able to formulate lesson plans because he has attended some workshops about the 2013 Curriculum as participant and even as an instructor.

This indicates that the English teacher has been autonomous in designing the incators which indicate higher order thinking skill. Teachers can be said to have autonomy when they involves the capacity, freedom, and/or responsibility to make choices concerning their own teachings. The learning activities in the entire lesson plans were split into three parts, such as pre-activity, whilstactivity, and post-activity. Pre-activities from those ten lesson plans generally involve some activities, namely greeting students with "Good morning" or "Good afternoon", checking students' attendance, praying, preparing students to be mentally and physically ready, giving motivation to the students, asking a question about the relation of the previous materials and the material to be learned through apperception, such as "Have you ever heard about advertisements?", explaining the learning objectives, delivering the scope of the study, and also individual activity, group activity, and task assessment technique. There was also a lesson plan which used game as a warming-up before starting the lesson. It was planned to be done in 10 minutes. Therefore, by looking at those activities in pre-activities, it can be said that the English teacher of SMA Negeri 2 Banjar has designed activities which match the government regulation.

In whilst-activity, the entire lesson plans designed the activities based on the steps in scientific approach, i.e. observing, questioning, exploring, associating, and communicating. In observing activities the English teacher planned to utilize interesting media to attract students' attention. For example, several of the lesson plans designed to use video to facilitate students in learning English. There were two activities in the observation step; the students were ordered to observe a video that concerns with language features and take a note of the important points of the video. However there were also some lesson plans which use picture as a media for the students. In observing activities, the students were observing some descriptive pictures about a tourism object and a famous historical building and students were ordered to observe three examples of advertisements in the form of picture.

Questioning phase is the second phase in scientific approach. In questioning phase of those lesson plans, it was found that the English teacher had planned to give chances for the students to ask questions. For instance, in several lesson plans were an activity had been designed. The activity is that the students had chances to ask questions that they wanted to know related to the video that was being observed. While in other lesson plans were proposed some activities, such as to fill out the form according to the conversation that was heard and was asked about the social functions and structure of the hotel form, e.g. have you ever filled a form? What kind of form?

Exploring phase is the third phase in scientific approach. It was found in exploring phase, the English teacher designed to use several numbers of leaning strategies such as group discussion and Q\&A (Question and Answer). However there was also another lesson plan which used group discussion only as a learning strategy. There were some activities in exploring phase which were designed by the teacher, for instance the teacher asked the students to make a group which consisted of four students and then the teacher asked the students in group to fill the blank with lyrics from the song given by the teacher. From the activities, it was indicated that the lesson designed to insert character values through learning strategies.

Associating activities is the fourth step in scientific approach. It was found that in the associating phase, the English teacher designed varied numbers of activities. The English teacher also employed learning technique, such as group work and lecturing technique. Most of the lesson plans which have designed by the English teacher required the students to work in group. The teacher asked the students in a group to differentiate the social function and the language feature from the two different examples of text and to write it in a piece of paper. It means that the use of cooperative learning technique was an attention from the teacher to develop character values.

Communicating is the last step in scientific approach. From all of the lesson plans, it was found that the English teacher gave chances to the students to conduct communicating activities. The teacher planned to use group work and a presentation technique. For instance, the teacher asked the students to make a short biography about B.J. Habibie and present it in front of the class. 
From the learning activities, it was indicated that the teacher used group work technique to develop students' cooperation ability. The teacher also related the activities in communicating to be relevant to the learning materials, i.e. social function, text structure, and language feature. There was also an activity in another lesson plan such as the teacher asked the students to retell the narrative text about Malin Kundang in front of the class, and teacher gave feedback towards students' performance. From those activities, it was indicated that the English teacher planned to use several techniques, i.e. cooperative learning technique and presentation technique to develop students' character. The learning activities also related to the learning materials, i.e. social function, text structure, and language feature.

By looking at the whilst-activity, it indicated that the English teacher has understood how to design the appropriate whilst-activities based on the 2013 Curriculum. However, those activities were not stated in the entire lesson plans. There were several lesson plans which did not indicating higher order thinking skill. The last is post-activity. Post-activities are done before closing a lesson. Based on the lesson plan, this session requires the teacher to ask the students whether or not they have questions about the lesson, ask the students to sing a song, and to tell about the activities on the next lesson. However there are also some other activities in another lesson plan such as giving feedback to the process of learning, asking the students to make the conclusion of the lesson, e.g. Is there anyone wants to conclude what we have learned today?, and to end the lesson by praying and saying "Good bye" to the students Thereby, it can be concluded that the English teacher was able to design a proper post-activity.

At the end of the learning process, the English teacher provided the students with varied exercises. There were varied numbers of questions provided in each lesson plan. They were completed with key answer and assessment procedure. In measuring students' skill, the teacher designed performance assessment in written or spoken skill. For example in the lesson plan in the theme of "Recount Text", the students were asked to write a Short Biography. In this writing the assessment was completed with a scoring rubric consisting of spelling, content, vocabulary, grammar, organization, and punctuation. Moreover in assessing speaking skill, the exercise was stated in another lesson plan under the theme of "Song". In this activity, the students in the group were required to deliver the meaning of the song in front of the class. It was also completed with the scoring rubric consisting of fluency, pronunciation, intonation, and diction.

Additionally, from the entire lesson plans, the exercises given by the teacher were in the form of essay. For example in the lesson plan under the theme of "Event Advertisement". There were fifteen exercises given by the teacher for two meetings. There were seven questions for indicator 3.7.1, a question for indicator 3.7.2, five questions for indicator 4.7.1, a question for indicator 4.7.2, and a question for indicator 4.7.3. All of those indicators assessed by scoring rubric design by the English teacher (see appendix 5 and 8). However, not all questions from each indicator were directed to higher order thinking skill. The English teacher started the questions by LOT (Low Order Thinking), which was followed by MOT (Medium Order Thinking), and ended it in HOT (Higher Order Thinking) in order to match with the students' background of knowledge.

It was found that the all of the lesson plans, the assessment of students' knowledge was in the form of essay. It indicated that the assessment designed by the teacher enables students to construct information provided. In assessing students' knowledge authentically, the teacher can ask the students to identify the text structure, the function, and language features of the text. For example in the lesson plan with the theme of "Report Text". The first question stated that "Please identify the generic structure of each paragraph of the text given!". It means that the English teacher has understood authentic assessment, but the assessment has not fulfilled the criteria of HOTS (Higher Order Thinking Skill) yet. Meanwhile the characteristics of assessment which belong to HOTS (Higher Order Thinking Skill) are (1) measuring high-level thinking skills, (2) based on contextual problems, (3) using various forms of questions, and (4) measuring cognitive levels such as C-4 (analyzing), C-5 (evaluating), and C-6 (creating) (Permendikbud No. 23 Tahun 2016). Based on the analysis of the entire lesson plan, the questions which belong to HOTS were stated in the skill aspect. For instances, "Please create a short and simple event advertisement based on the themes that are 
given by the teacher!", "Please analyze fill in the blank space of the lyric!". In the first example, the operational verb "create" was used which belongs to C6 in revised Bloom's Taxonomy. Likewise with the second example, the operational verb "analyze" was used which belongs to C4 in revised Bloom's Taxonomy. In so doing, it indicated that Higher Order Thinking Skill was not state in all of the exercises, but only in the skill aspect.

\section{Conclusion}

Based on the findings and discussions, the researcher concluded some points related to the indicators, learning activity, and the class assessment in the lesson plan which consists of Higher Order Thinking Skill (HOTS) at SMA Negeri 2 Banjar. There were several operational verbs which were used by the teacher in designing indicator, such as identifying, creating, and showing. The material were taken from some resources, namely English Textbook, internet, even the teacher developed the material themselves. The learning media already involved visual, audio, and audio visual which aimed at fostering the students' participation in learning that were supported with some learning tools, i.e. computer, LCD, and speaker.

The learning activities were in the form of pre-activities, whilst-activities, and post activities. In designing whist-activities, it can be seen that the teacher used several strategies, such as pair-work, interview, and group work which aimed at developing the character of the students. In designing those pre-activities, whilst-activities, and post-activities, the English teacher was able to design the proper activities based on the curriculum 2013.

The assessment which was used to assess the students was authentic assessment in the form of essay which makes students create the information themselves. The English teacher provided several questions in the lesson plan from knowledge and skill aspect. Based on the characteristics of assessment which belong to HOTS (Higher Order Thinking Skill) there are (1) measuring high-level thinking skills, (2) based on contextual problems, (3) using various forms of questions, and (4) measuring cognitive levels such as C-4 (analyzing), C-5 (evaluating), and C-6 (creating). Based on the analysis of the entire lesson plan, the questions which belong to HOTS were stated in the skill aspect. In so doing, it indicated that Higher Order Thinking Skill was not state in all of the exercises, but only in the skill aspect.

In short, from the result of the interview, it can be indicated that the English teacher did not have any problem in designing assessment which belong to Higher Order Thinking Skill. However, he had a problem in adjusting with the background of the students. The English teacher usually designed the exercises by starting them by LOT questions, continued by MOT questions, and ended by HOT questions. The aim of this research is that to analyze the content of lesson plan and assessment in SMA Negeri 2 Banjar related to indicator of higher order thinking skill. Based on the result of data analysis through document analysis, it can be concluded that from the entire lesson plans used there were several parts which can be categorized as Higher Order Thinking Skill (HOTS).

\section{References}

Anderson, \& Krathwohl. (2001). Anderson and Krathwohl Bloom's Taxonomy Revised .

Creswell. (2009). The Selection of a Research Design.

Mainali, B. (2012). Higher Order Thinking Skill in Education. A Multidisciplinary Journal, 5.

Nilamsari, N. (2014). Memahami Studi Dokumen dalam Penelitian Kualitatif.

Nourdad, N., Masoudi, S., \& Rahimali, P. (2018). The Effect of Higher Order Thinking Skill Instruction on EFL Reading Ability. International Journal of Applied Linguistics \& English Literature, 1.

Peraturan Menteri Pendidikan dan Kebudayaan Republik Indonesia. (2013). Nomor 81A Tahun 2013 tentang Implementasi Kurikulum.

Peraturan Menteri Pendidikan dan Kebudayaan Republik Indonesia. (2013). Nomor 65 Tahun 2013 tentang Standar Proses Pendidikan Dasar dan Menengah. 
Peraturan Menteri Pendidikan dan Kebudayaan Republik Indonesia. (2014). Nomor 104 tahun 2014 Tentang Penilaian Hasil Belajar oleh Pendidik pada Pendidikan Dasar dan Pendidikan Menengah.

Peraturan Menteri Pendidikan dan Kebudayaan Republik Indonesia. (2016). NOMOR 23 TAHUN 2016 Tentang Standar Penilaian Pendidikan .

Saido, G., Siraj , S., Nordin, A., \& Al_Amedy, O. (2015). Higher Order Thinking Skills Among Secondary School Students in Science Learning. The Malaysian Online Journal of Educational Science, 14.

Sandelowski, M. (2000). Fokus on Research Method: Whatever happened to qualitative description. Univercity of North California.

Sulaiman, T., Muniyan, V., Madhvan, D., Hasan , R., \& Rahim , S. (2017). Implementation of Higher Order Thinking Skills in Teaching Of Science: A Case Study in Malaysia . International Research Journal of Education and Sciences (IRJES) , 1.

Syahputra, E., \& Surya, E. (2017). The Development of Learning Model Based on Problem Solving to Construct High-Order Thinking Skill on the Learning Mathematics of 11 th Grade in SMA/MA. Journal of Education and Practice, 80.

Tomlinson, B. (2011). Material Develpment in Language Teaching (2nd ed). Cambridge: Cambridge University Press.

Widana, I., Parwata , I., Parmithi, N., Jayantika, I., Sukendra, K., \& Sumandya, I. (2018). Higher Order Thinking Skills Assessment towards Critical Thinking on Mathematics Lesson . International Journal of Social Sciences and Humanities , 24.

Winarti, Cari, Sunarno, W., \& Istiyono, E. (2015). Analysis of Higher Order Thinking Skills Content of Physics Examinations in Madrasah Aliyah. International Conference on Mathematics, Science, and Education. 